\title{
The Presence of Foreign Capital and the Internationalization of Portuguese Industrial SMEs
}

\author{
Luís Pacheco ${ }^{1, *}$, Carla Lobo ${ }^{1}$ and Isabel Maldonado ${ }^{1,2}$ (D) \\ 1 REMIT, Department of Economics and Management, Universidade Portucalense, 4200-027 Porto, Portugal; \\ cadsa@upt.pt \\ 2 GOVCOPP (Aveiro-Portugal), Campus Universitário de Santiago, 3810-193 Aveiro, Portugal; ianm@upt.pt \\ * Correspondence: luisp@upt.pt
}

check for updates

Citation: Pacheco, Luís, Carla Lobo, and Isabel Maldonado. 2022. The Presence of Foreign Capital and the Internationalization of Portuguese Industrial SMEs. Journal of Risk and Financial Management 15: 68. https://doi.org/10.3390/ jrfm15020068

Academic Editor: Marc Deloof

Received: 22 December 2021

Accepted: 28 January 2022

Published: 2 February 2022

Publisher's Note: MDPI stays neutral with regard to jurisdictional claims in published maps and institutional affiliations.

Copyright: (C) 2022 by the authors. Licensee MDPI, Basel, Switzerland. This article is an open access article distributed under the terms and conditions of the Creative Commons Attribution (CC BY) license (https:// creativecommons.org/licenses/by/ $4.0 /)$.

\begin{abstract}
The objective of this paper is to empirically examine the relationship between the firms' ownership and control structure, in particular the presence of foreign capital, and their internationalization levels, measured in terms of intensity and diversification. The international performance of Portuguese SMEs, which is crucial for the domestic economy's growth, depends on a multitude of factors, with the existence of foreign investment inflows directed to industrial SMEs being a usually forgotten factor. This paper fills that gap using a balanced panel data of 5722 firms for the period from 2010 to 2017, researching if the presence of foreign capital influences the level and scope of internationalization, and controlling the effects of other variables such as profitability, age, size, indebtedness and sector of activity. The origin of foreign capital is also considered, being researched if issues of institutional or development differences exert any influence over firms' internationalization. The results evidence that the presence of foreign shareholders in SMEs positively influences internationalization and that the distance variable positively correlates with the internationalization measures. Moreover, there seems to exist a non-linear relationship between the development level of the country of origin of the share capital and internationalization, with the results indicating that firms with share capital originating from more advanced countries attain a higher degree of internationalization. As SMEs in Portugal face increasing competition, joining hands with resource-rich investors such as foreign corporations and institutional investors would be a fruitful strategy to enhance the international competitiveness of Portuguese firms.
\end{abstract}

Keywords: ownership structure; internationalization; foreign investment; SMEs; manufacturing sector

JEL Classification: G32; F23

\section{Introduction}

The debate on factors affecting the international development of small and mediumsized enterprises (SMEs) has become widespread, attracting a continuous interest in the literature. Traditionally, the literature extensively emphasized the obstacles or barriers to internationalization and the main factors enhancing SMEs' international activities (Lu and Beamish 2001; Bell et al. 2004; Fernández and Nieto 2006; Fernandez-Ortiz and Lombardo 2009; Sommer 2010; Cerrato and Piva 2012).

Given the limitations of the internal market, internationalization can provide potential returns to an individual firm (Gande et al. 2009; Hitt et al. 2006) due to two main reasons: (i) internationalization offers opportunities for value creation, providing access to new resources, knowledge, business practices and foreign stakeholders; (ii) internationalization contributes to the reduction of fluctuations in revenue by diversifying risks over several countries. 
Nevertheless, SMEs suffer from a number of major internal handicaps to international development related to their limited endowment of resources and capabilities; therefore, it will be relevant to study this phenomenon from a different perspective. Specifically, since it can be argued that the firm's resources and capabilities are a result of the type of ownership, then the use of those resources and capabilities will impact the international strategy of the firm. In this context, this paper empirically examines the relationship between firms' ownership and control structure, in particular the presence of foreign capital, and their level of internationalization.

Previous research on governance systems has broadly studied the differences between concentrated and diffusely distributed share ownership structures, with the special role played by ownership in international business being highlighted. Ownership structure can be a factor affecting and stimulating SMEs' internationalization, especially related to the foreign versus domestic ownership structure (Anil et al. 2014; Larimo and Arslan 2013; Wach 2017). However, ownership structure can affect internationalization in different ways depending on various ownership-stake related aspects. That said, there are few studies examining the influences of different types of ownership on the strategic behavior of SMEs (Singla et al. 2017), the owners' identity has important implications for firm strategy and performance (Thomsen and Pedersen 2000; George et al. 2005). Different types of ownership can affect the firm's objectives, including the decision to internationalize, because distinct types of owners have differing values, incentives and preferences (Fernández and Nieto 2006; Lin 2012). Boyd and Solarino (2016) also reinforced that the existent literature primarily examined family and institutional owners. Given our focus on internationalization, here we explore the effect of a specific type of ownership-the presence of foreign shareholders - on internationalization, thus contributing to this body of research.

The analysis of the influence of different degrees of foreign ownership on firm internationalization is particularly relevant for Portugal, a country where joint-ventures (JVs) and wholly foreign-owned firms coexist. Wholly foreign-owned firms are subsidiaries of a foreign parent company, which has full ownership and responsibility of the domestic operation. JVs imply that a local and a foreign partner share the ownership, management, risks and rewards of the joint entity. According to the Portuguese Statistics Office (INE 2018), there are 6455 foreign subsidiaries operating in the country (1.6\% of all non-financial firms), a number that is a reflection of the country's peripheral nature. Intra-EU companies own the majority of firms, most of them SMEs with above average productivity levels, paying higher wages and more being present in the commerce, construction and industrial sectors.

Using a balanced panel data of 5722 SMEs for the period 2010-2017, the present study fills a gap in the literature since: (i) it distinguishes not only between domestic and foreignowned firms, but also between wholly and partly foreign-owned firms; and (ii) it examines the possible non-linear nature of the ownership-internationalization relation. The choice of a national data set allows the comparison of our results with similar studies in other countries (e.g., Fernández and Nieto 2006; Lin 2012; Gaur and Delios 2015; Wach 2017). From this comparison we expect to evidence country-specific factors influencing the internationalization of SMEs (Narayanan 2015; Stouraitis et al. 2017) and at the same time understand the importance of the internationalization-promoting channel of FDI, particularly when assuming the form of JVs. The relevance of this line of research for policy is clear, since the identification of the firm-level factors that cause export activity would inform outward-orientated promotion policies.

The rest of the paper is structured as follows. The next section reviews the literature dealing with the relation between foreign ownership and internationalization. This section also presents the other determinants of internationalization and the hypotheses to be tested. Section three presents the variables, the data and the methodology to be used and the following sections present and discuss the empirical results. The final section highlights some concluding aspects. 


\section{Literature Review}

With globalization, good export performance, whether measured in terms of scale or scope, is increasingly a critical factor for the overall performance and survival of companies, and for many companies it represents a natural development.

Exporting is generally the first stage of the process of internationalization (Johanson and Vahlne 1977) and is the most common foreign market entry mode among SMEs, given the greater flexibility and lower business risk and resource commitment compared to other ways of entering foreign markets (Leonidou 2004; Ruzzier et al. 2006; Leonidou et al. 2007). International business literature has advanced a set of strategies and determinants of international diversification and trade (Buckley and Casson 1976; Johanson and Vahlne 1977; Dunning 1980), highlighting the associated benefits and costs (Zaheer 1995).

Different theoretical frameworks suggest several factors on the pace of internationalization. These can be classified as to whether internal resource factors (such as market knowledge and the resource base of the firm) or external factors (such as market volume and the competitive environment) are stressed (Pedersen and Petersen 1998; Sousa et al. 2008). For individual firms, entering the export market constitutes a high-risk decision that encompasses sunk costs, revenue volatility due to exchange rate movements, limited knowledge of external market conditions, local competition and cultural assimilation (Rocco 1996). Different internal or firm-specific characteristics such as size, age, productivity and product diversification have been shown to be associated with SMEs internationalization (Graves and Thomas 2004; Kontinen and Ojala 2010; Pacheco 2017).

The present study focuses on the determinants of firm internationalization assessing if internationalization is impacted by the presence, magnitude and origin of foreign capital. Firm internationalization is a multidimensional construct heavily researched in the literature (e.g., Venkatraman and Ramanujam 1986), but in the present paper we are focused on the relation of internationalization with the firm's ownership structure, in particular the effects of foreign ownership. The impact of corporate governance on firms' strategic decision-making and performance has been well documented in the literature (e.g., Demsetz and Villalonga 2001), but mostly for large and listed firms. Nevertheless, the peculiarities of SMEs and the relation of foreign capital with the different firms' internationalization levels have received less attention.

According to Gaur and Delios (2015), a large body of literature researches the relationship between ownership structure and different firm-level outcomes, such as diversification (Ramaswamy et al. 2002), innovation strategies (Hoskisson et al. 2002) and financial performance (Shleifer and Vishny 1997; Himmelberg et al. 1999; Thomsen and Pedersen 2000; Joh 2003). However, limited research investigates how ownership structure affects a firm's internationalization strategy (some examples are Zahra 2003; Kontinen and Ojala 2011; Sciascia et al. 2012; Majocchi and Strange 2012; Singh and Gaur 2013). Those effects should be studied in light of the agency theory.

Agency theory primarily centers on conflicts between different stakeholders, suggesting that concentrated ownership makes it easier for owners to monitor and control managers, who may be working to satisfy their personal goals rather than organizational goals (Jensen and Meckling 1976; Shleifer and Vishny 1997). Agency problems become aggravated by international diversification, because foreign investments provide managers with greater freedom to pursue their own self-interests compared with domestic investments (Morck et al. 1990).

According to Singla et al. (2017), the principal-principal agency theory argues that owner concentration combined with identity differences among owners, such as family, institutional, foreign, domestic and corporate owner categories (Douma et al. 2006; Villalonga and Amit 2006), could lead to different risk preferences, goals and time horizons, spurring the inclinations among dominant owners to appropriate the private benefits of control. These inclinations create differences in owners' and firms' motivations to pursue different strategic decisions such as internationalization. Namely, the impact of ownership structure on corporate strategy and firm performance has been widely researched 
in the management field with several studies providing empirical evidence that ownership structure impacts a firm's foreign expansion strategy (Thomsen and Pedersen 2000; Tihanyi et al. 2003; Zahra 2003; George et al. 2005; Filatotchev et al. 2007; Lu et al. 2009; Bhaumik et al. 2010).

Variation in ownership has traditionally been studied in relation to ownership dispersion/concentration. However, it is also important to focus on the different kinds of ownership. Ownership structure, particularly in terms of the identity of the owner, has also been found to drive SMEs' strategies, including internationalization, as the type of ownership may affect both the degree of risk aversion and the set of resources and capabilities the SME can leverage (Gedajlovic and Shapiro 1998; Thomsen and Pedersen 2000; George et al. 2005; Fernández and Nieto 2006; Cerrato and Piva 2012). For instance, Fernández and Nieto (2006) provided empirical support for the hypothesis that a corporate blockholder encourages an SME to expand internationally (for a sample of 6000 family SMEs in Spain). Using a sample of 1324 Italian manufacturing SMEs, Cerrato and Piva (2012) evidenced that the presence of foreign shareholders positively affects the likelihood of going international. According to Wach (2017), such a positive relation is clearly illustrated by many research studies worldwide, and it seems obvious that international investors provide unique knowledge about international markets (Wach 2014), making the international commitment much easier and implementing the assumptions of the U-model of internationalization (Johanson and Wiedersheim-Paul 1975; Johanson and Vahlne 1977), especially supported by the networking and international links of a foreign investor (Johanson and Vahlne 2009).

A comprehensive analysis of the relationship between ownership structure and internationalization is not within the scope of this paper. Rather, we are interested in exploring the effect of a specific ownership characteristic - the presence of foreign shareholders-on the internationalization of SMEs. Foreign corporations are foreign owners who have strategic equity stakes in domestic or host country firms. Such corporates with ownership stakes are not motivated purely by financial goals, but are also motivated by the desire to develop worldwide competitive advantages and capabilities, and thereby capture new markets, without the constraint of perceiving internationalization as a risky strategy because those corporate owners have prior international experience. However, foreign ownership signals a greater knowledge of the international environment and may be indicative of a wider view of markets too (Fernández and Nieto 2006).

Since different owners possess and/or have access to different types of resources, access to these resources enables firms to pursue uniquely different strategies such as internationalization. Several authors argued that foreign-owned subsidiaries possess a set of firm-specific advantages that are not available to domestic firms, such as access to financial, technological, marketing and human resources, or the capability to exploit economies of scale, enhancing their performance and results (Liesch and Knight 1999; Harris and Robinson 2003; Yudaeva et al. 2003; Caves 2007; Girma and Görg 2007; Temouri et al. 2008; Halkos and Tzeremes 2010). Moreover, foreign firms invest in domestic firms to access local markets, including their location-specific productive resources (Anand and Delios 1996). The presence of foreign owners increases the possibilities for international expansion if their objective is to gain access to the productive resources of global markets. Additionally, foreign owners bring several competitive benefits to domestic firms. In particular, they provide the domestic firm with access to lower financing costs, technical and managerial expertise (Zhang and Bulcke 1996) and useful connections to international markets (Chhibber and Majumdar 2005).

A large number of studies present the limitations of adopting a narrow measure, simply using a dummy variable to distinguish between foreign-owned and domesticowned firms, without analyzing the situations in-between (e.g., the presence of JVs, with varying degrees of ownership). For instance, when studying different countries and time periods, several authors evidenced that firms with different degrees of foreign ownership performed distinctively (Blomström and Sjöholm 1999; Dimelis and Louri 2002; Greenaway et al. 2014). 
Following the literature presented above and grounded on the agency theory and the resource-based view (RBV) of the firm (Wernerfelt 1984; Barney 1991), it is hypothesized that foreign ownership is positively related to internationalization.

Differences in internationalization levels can be the result of differences in firm-specific advantages, as well as differences in industry's characteristics where firms operate. Empirical studies on factors influencing internationalization have shown that industry classification is a relevant factor, since industries present different capital structures, resources' demand and products with different levels of marketability. Thus, following Cerrato and Piva (2012) and Singla et al. (2017) it is important to study if there are significant sectoral differences between foreign-owned and domestic firms, classifying firms according to their technological intensity.

Another interesting topic, rooted in the institutional economics literature, is the issue of development differences and institutional distances. The question at hand is whether internationalization could be affected by the country of origin of share capital and its development/institutional distance in relation to the host country (e.g., Chari and Shaikh 2017). Potentially, a higher "institutional distance" increases firm's internationalization levels given the use of specific resources or knowledge (Zaheer and Hernandez 2011).

As a result of the above, we can now state a first set of hypotheses to be tested:

Hypothesis 1 (H1). The degree of foreign ownership is positively related with firm internationalization.

Hypothesis 1a (H1a). Foreign ownership has a positive effect on export intensity and diversification.

Hypothesis $\mathbf{1 b} \mathbf{( H 1 b ) . ~ T h a t ~ e f f e c t ~ i s ~ n o n - m o n o t o n i c . ~}$

Hypothesis 1c (H1c). That effect differs between industries.

Hypothesis 2 (H2). Firms with foreign share capital coming from more institutionally developed countries present higher levels of internationalization.

Notwithstanding the focus of our paper on the relation between foreign presence in firms' equity and internationalization, a set of control variables is included in order to rule out alternative determinants of firms' internationalization. Besides their direct impact on internationalization, we also intend to explore the moderating role of some of these variables. These variables are traditionally used in studies about internationalization determinants: firm profitability, age, size and debt (Kwok and Reeb 2000; Manolova et al. 2002; Dhanaraj and Beamish 2003; Fernández and Nieto 2006; Cerrato and Piva 2012; Pacheco 2017). So, in line with the previous literature, we present the following set of additional hypotheses:

Hypothesis 3 (H3). The relation between foreign ownership and internationalization differs between less and more profitable firms, the latter presenting higher levels of internationalization.

Hypothesis $4 \mathbf{( H 4 ) . ~ T h e ~ r e l a t i o n ~ b e t w e e n ~ f o r e i g n ~ o w n e r s h i p ~ a n d ~ i n t e r n a t i o n a l i z a t i o n ~ d i f f e r s ~}$ between younger and older firms, the latter presenting higher levels of internationalization.

Hypothesis $\mathbf{5}(\mathbf{H} 5)$. The relation between foreign ownership and internationalization differs between larger and smaller firms, the former presenting higher levels of internationalization.

Hypothesis 6 (H6). The relation between foreign ownership and internationalization differs between more or less indebted firms, the latter presenting higher levels of internationalization. 


\section{Methods}

\subsection{Dependent and Independent Variables}

In an attempt to characterize the several dimensions of "export performance", this paper uses two different variables: export intensity and export diversification. The simpler export intensity variable is measured by total exports as a percentage of total sales (EXP). Concerning export diversification, studies reported in the literature use different measures, so a consensus is still lacking on the best or true measure of international diversification (Majocchi and Strange 2012; Boehe and Jiménez 2016). Some possible measures are the foreign sales percentage, the foreign tax ratio, the export sales growth or profitability, the number of countries in which the firm operates, entropy measures of the firm's geographical diversification and composite indexes. The use of a uni-dimensional measure such as the ratio of foreign sales to total sales does not take into account the geographical distribution of sales, i.e., whether or not they are geographically well balanced in major world markets (Boehe and Jiménez 2016).

Accordingly, we use a measure of entropy, which accounts for the dispersion or diversification of a firm's international sales. Considering the distribution of total exports in two main geographical areas (given the availability of data, the European Union and the rest of the world), we developed a measure of international diversification (INT) based on the Kim (1989) entropy index that has been extensively used in recent studies on international diversification (Majocchi and Strange 2012).

$$
\text { Index of international diversification }(\mathrm{INT})=\sum_{\mathrm{j}=1}^{2} \mathrm{x}_{\mathrm{j}} \ln \left(\frac{1}{\mathrm{x}_{\mathrm{j}}}\right)
$$

The subscript $j$ defines one of the two markets and $x_{j}$ is the percentage of sales realized in market $j$. The natural logarithm of the inverse of the sales realized in every market is the weight given to each geographical segment. The entropy measure will equal zero for firms that have all their sales concentrated in one region, and will reach a maximum value of 0.693 for firms with exactly the same share of sales in each of the two defined areas. Nevertheless, as stated by Majocchi and Strange (2012), such a measure also has some weaknesses: it is not expected that a firm's level of international sales will be evenly distributed between destiny areas, and an ideal measure of internationalization should not only measure the dispersion of foreign sales but also their level.

The independent variable foreign ownership (FO) is computed as the percentage of the firm's capital that is foreign-owned. This constitutes the usual way to measure foreign ownership, and was employed by Halkos and Tzeremes (2010), Greenaway et al. (2014), Konings (2001) and Hintosova and Kubikova (2016) among others. Following Cerrato and Piva (2012), and consistent with some other previous studies (e.g., Fernández and Nieto 2006), the participation of foreign shareholders in the SME is also measured through a dummy variable (DUM_FO), which is 1 if one of the four largest shareholders is a foreigner, 0 otherwise. As our sample consists entirely of SMEs, focusing on the first four shareholders can be considered enough to have an exhaustive picture of the firm's ownership structure. On average, foreign owners' control $85 \%$ of the equity in firms where a foreign owner is present.

We assume that when the foreign capital comes from a more institutionally developed country than the host-country that it should be beneficial for the firm, because it benefits from the experience and cost-efficient methods brought from abroad. So, the variable institutional difference (INST) between the host-country and the country of origin of the capital is measured using the Heritage Index of Economic Freedom (Holmes et al. 2008). This index ranges from 0 to 100, with higher values indicating greater economic development, being INST measured by the difference between Portugal's and the country-of-origin yearly indexes. So, it is expected to be a negative relation, since positive (negative) values for INST indicate that Portugal is more (less) institutionally developed than the country of origin. Additionally, alternatively to INST and as a robustness check, the differences between 
Portugal and the capital's country of origin in terms of HDI (Human Development Index) and GDP per capita (in PPP) are also tested.

\subsection{Control Variables}

Even though our paper is focused on the relation between the degree of foreign ownership and internationalization, we include the following set of control variables: profitability, age, size and debt.

Profitability is measured by ROA, computed as net income divided by the book value of total assets. For kurtosis reasons, variables age (AGE) and size (SIZ) are measured, respectively, as the log of the number of years since the firm's inception and the log of total assets. The debt level of the firm is measured as total debt (TD = Total liabilities/Total assets) and its subdivision in short-term and long-term debt (respectively, Current liabilities/Total assets and Non-current liabilities/Total assets).

\subsection{Data and Methodology}

This paper analyses a sample of SMEs from the industrial sectors (codes 10 to 32, from the European Classification of Economic Activities-NACE-Rev. 2) obtained from SABI (Sistema de Análise de Balanços Ibéricos), a financial database powered by Bureau van Dijk (with the exception of the variables that measure "institutional difference", HDI and GDP per capita). Applying the criteria for SMEs definition (Commission Recommendation $2003 / 361 / E C)$, leads to the exclusion of a large number of micro firms employing less than 10 persons and with annual turnover and/or annual balance sheet not exceeding EUR 2 million. Considering only firms already existing in 2010 and presenting complete data from 2010 to 2017, excluding firms with negative debt ratios, equity and liabilities greater than assets, a ratio of foreign sales to total sales or foreign assets to total assets greater than 1 and winsorizing the observations below (and above) the 1st (and 99th) percentile, in order to eliminate spurious outliers (Barber and Lyon 1996), we obtained a balanced panel data of 5722 SMEs distributed by all industrial sectors.

Table 1 presents a description of our sample. The sample is constituted by mature SMEs, with an average age of 30 years, accounting for 229,708 employees, total assets of EUR 23.930 million, a turnover near EUR 23,000 million and an average ROA of 2.9\% in 2017. In total, $76.4 \%$ of the sample are small firms (4372) and $23.6 \%$ are medium firms (1350) and the average percentage of foreign ownership is around 4\%. A total of 269 firms have partial or total foreign ownership, with share capital coming from 28 different countries. In those 269 firms, there are 198 wholly foreign-owned firms and $71 \mathrm{JVs}$ with an average ROA of $4.2 \%$ and $3.0 \%$, respectively. Finally, foreign ownership is more relevant in highly capital-intensive sectors, such as sectors 19/20/21, 26, 29 and 30.

Before estimating the different models, we present in Table 2 some descriptive statistics and the variables correlation matrix. The table presents the sample's mean values for the different variables, distinguishing between the two types of firms, together with the results for a difference in mean values test. The $t$-test evidences significant differences between domestic and foreign-owned firms. Foreign firms present better performance indicators, are larger, export-oriented and display lower levels of indebtedness. The preference of foreign firms for larger size and less debt may contribute to the significant difference in terms of profitability. 
Table 1. Distribution of the sample by industry classifications.

\begin{tabular}{|c|c|c|c|c|c|c|c|}
\hline $\begin{array}{l}\text { Industry Classification } \\
\text { (NACE) }\end{array}$ & $\begin{array}{l}\text { Number } \\
\text { of Firms }\end{array}$ & $\begin{array}{l}\text { Small } \\
\text { Firms } \\
(\%)\end{array}$ & $\begin{array}{l}\text { Aver. } \\
\text { Number } \\
\text { of Empl. }\end{array}$ & $\begin{array}{l}\text { Average } \\
\text { Sales } \\
\text { (th EUR) }\end{array}$ & $\begin{array}{l}\text { Exports } \\
\text { (\%) }\end{array}$ & $\begin{array}{l}\text { Average } \\
\text { EBITDA } \\
\text { (th EUR) }\end{array}$ & $\begin{array}{c}\text { Foreign } \\
\text { Ownership } \\
(\%)\end{array}$ \\
\hline Food products (10) & 821 & $78.6 \%$ & 36.2 & 5049.0 & $7.6 \%$ & 351.1 & $2.4 \%$ \\
\hline $\begin{array}{l}\text { Beverages and tobacco } \\
(11 / 12)\end{array}$ & 129 & $88.4 \%$ & 26.5 & 4702.1 & $27.7 \%$ & 741.1 & $7.0 \%$ \\
\hline Textiles (13) & 327 & $71.2 \%$ & 47.8 & 4756.4 & $32.0 \%$ & 496.4 & $3.2 \%$ \\
\hline Wearing apparel (14) & 457 & $66.1 \%$ & 52.0 & 3795.2 & $61.5 \%$ & 265.4 & $1.4 \%$ \\
\hline $\begin{array}{l}\text { Leather and related } \\
\text { products (15) }\end{array}$ & 394 & $58.9 \%$ & 53.7 & 3869.3 & $49.2 \%$ & 281.9 & $2.0 \%$ \\
\hline $\begin{array}{l}\text { Wood and of products of } \\
\text { wood and cork (16) }\end{array}$ & 323 & $86.4 \%$ & 30.8 & 3584.6 & $26.3 \%$ & 335.4 & $2.0 \%$ \\
\hline $\begin{array}{l}\text { Paper and paper } \\
\text { products (17) }\end{array}$ & 108 & $68.5 \%$ & 51.4 & 7452.4 & $15.3 \%$ & 724.9 & $10.1 \%$ \\
\hline $\begin{array}{l}\text { Printing and reproduction } \\
\text { of recorded media (18) }\end{array}$ & 199 & $86.4 \%$ & 29.6 & 2161.4 & $5.2 \%$ & 306.7 & $0.5 \%$ \\
\hline $\begin{array}{l}\text { Refined petroleum, } \\
\text { chemicals, man-made } \\
\text { fibers and pharmaceutical } \\
\text { products }(19 / 20 / 21)\end{array}$ & 161 & $73.9 \%$ & 44.5 & 7431.9 & $19.0 \%$ & 753.9 & $16.7 \%$ \\
\hline $\begin{array}{c}\text { Rubber and plastic } \\
\text { products }(22)\end{array}$ & 306 & $73.2 \%$ & 44.0 & 5512.5 & $23.7 \%$ & 692.6 & $6.9 \%$ \\
\hline $\begin{array}{l}\text { Other non-metallic } \\
\text { mineral products (23) }\end{array}$ & 443 & $81.0 \%$ & 34.8 & 3008.8 & $30.7 \%$ & 426.2 & $4.0 \%$ \\
\hline Basic metals (24) & 55 & $61.8 \%$ & 52.8 & 7503.2 & $34.6 \%$ & 824.3 & $4.6 \%$ \\
\hline $\begin{array}{l}\text { Fabricated metal } \\
\text { products }(25)\end{array}$ & 995 & $80.7 \%$ & 35.7 & 3153.1 & $27.2 \%$ & 404.1 & $3.6 \%$ \\
\hline $\begin{array}{l}\text { Computer, } \\
\text { communication and } \\
\text { electronic equip. (26) }\end{array}$ & 27 & $66.7 \%$ & 61.4 & 7037.7 & $36.5 \%$ & 618.7 & $11.1 \%$ \\
\hline Electrical equipment (27) & 111 & $77.5 \%$ & 40.5 & 4260.5 & $30.0 \%$ & 437.5 & $9.7 \%$ \\
\hline $\begin{array}{l}\text { Machinery and } \\
\text { equipment (28) }\end{array}$ & 285 & $76.5 \%$ & 40.3 & 3916.3 & $32.7 \%$ & 482.6 & $5.5 \%$ \\
\hline $\begin{array}{l}\text { Motor vehicles, trailers } \\
\text { and parts (29) }\end{array}$ & 86 & $62.8 \%$ & 53.0 & 4874.2 & $40.5 \%$ & 521.2 & $12.8 \%$ \\
\hline $\begin{array}{l}\text { Other transport } \\
\text { equipment (30) }\end{array}$ & 22 & $54.6 \%$ & 58.7 & 6106.5 & $45.2 \%$ & 625.9 & $18.2 \%$ \\
\hline Furniture (31) & 341 & $82.1 \%$ & 32.0 & 1947.8 & $32.7 \%$ & 218.1 & $0.9 \%$ \\
\hline $\begin{array}{l}\text { Other manufacturing } \\
\text { activities (32) }\end{array}$ & 132 & $84.9 \%$ & 31.3 & 2073.0 & $19.3 \%$ & 193.7 & $6.1 \%$ \\
\hline Averages/totals & 5.722 & $76.4 \%$ & 40.1 & 4019.0 & $28.6 \%$ & 411.9 & $4.0 \%$ \\
\hline
\end{tabular}

Note: Small firms are firms with less than 50 employees. Sectors 11/12 and 19/20/21 are aggregated since the sample only comprises a very small number of firms in sectors 12, 19 and 21.

Regarding the correlation coefficients, they are generally low with foreign ownership being negatively correlated with institutional difference, meaning that foreign capital comes mainly from more developed countries. 
Table 2. Descriptive statistics and correlation matrix between independent variables.

\begin{tabular}{|c|c|c|c|c|c|c|c|c|c|c|}
\hline & $\begin{array}{c}\text { Domestic } \\
\text { Firms } \\
(n=5453)\end{array}$ & $\begin{array}{c}\text { Foreign } \\
\text { Firms } \\
(n=269)\end{array}$ & $\begin{array}{c}\text { Mean } \\
\text { Differ. } \\
\text { ( } t \text {-Test) }\end{array}$ & FO & INST & ROA & AGE & SIZ & STD & LTD \\
\hline EXP & $26.3 \%$ & $52.5 \%$ & $\begin{array}{c}32.13 \\
(* * *)\end{array}$ & $\begin{array}{c}0.164 \\
(* * *)\end{array}$ & $\begin{array}{c}-0.118 \\
(* * *)\end{array}$ & $\begin{array}{c}0.085 \\
(* * *)\end{array}$ & $\begin{array}{c}0.038 \\
(* * *)\end{array}$ & $\begin{array}{c}0.277 \\
(* * *)\end{array}$ & $\begin{array}{c}0.073 \\
(* * *)\end{array}$ & $\begin{array}{c}-0.048 \\
(* *)\end{array}$ \\
\hline INT & 0.16 & 0.25 & $\begin{array}{l}3.35 \\
(* * *)\end{array}$ & $\begin{array}{c}0.072 \\
(* * *)\end{array}$ & $\begin{array}{c}-0.068 \\
(* * *)\end{array}$ & $\begin{array}{c}0.016 \\
(* * *)\end{array}$ & $\begin{array}{c}0.136 \\
(* * *)\end{array}$ & $\begin{array}{l}0.035 \\
(* * *)\end{array}$ & $\begin{array}{c}-0.044 \\
(* * *)\end{array}$ & $\begin{array}{c}-0.008 \\
\left.{ }^{*}\right)\end{array}$ \\
\hline $\mathrm{FO}$ & $\ldots$ & $85.7 \%$ & $\ldots$ & 1 & $\begin{array}{c}-0.535 \\
(* * *)\end{array}$ & $\begin{array}{c}0.034 \\
(* * *)\end{array}$ & $\begin{array}{c}0.007 \\
(* * *)\end{array}$ & $\begin{array}{c}0.222 \\
(* * *)\end{array}$ & $\begin{array}{c}-0.015 \\
(* * *)\end{array}$ & $\begin{array}{c}-0.050 \\
\left({ }^{* * *}\right)\end{array}$ \\
\hline INST & $\ldots$ & -4.6 & $\ldots$ & & 1 & $\begin{array}{c}-0.042 \\
(* * *)\end{array}$ & -0.003 & $\begin{array}{c}-0.148 \\
(* * *)\end{array}$ & $\begin{array}{c}0.025 \\
(* * *)\end{array}$ & $\begin{array}{c}0.030 \\
\left({ }^{* * *}\right)\end{array}$ \\
\hline ROA & $2.9 \%$ & $3.9 \%$ & $\begin{array}{l}5.62 \\
(* * *)\end{array}$ & & & 1 & $\begin{array}{c}-0.091 \\
(* * *)\end{array}$ & $\begin{array}{l}0.049 \\
(* * *)\end{array}$ & -0.123 & $\begin{array}{c}-0.170 \\
(* * *)\end{array}$ \\
\hline AGE & 3.1 & 3.1 & 0.69 & & & & 1 & $\begin{array}{c}0.285 \\
(* * *)\end{array}$ & $\begin{array}{c}-0.217 \\
(* * *)\end{array}$ & $\begin{array}{c}-0.111 \\
(* * *)\end{array}$ \\
\hline SIZ & 7.4 & 8.7 & $\begin{array}{c}56.96 \\
(* * *)\end{array}$ & & & & & 1 & $\begin{array}{c}-0.086 \\
(* * *)\end{array}$ & 0.007 \\
\hline STD & $41.1 \%$ & $39.0 \%$ & $\begin{array}{c}-4.46 \\
(* * *)\end{array}$ & & & & & & 1 & $\begin{array}{c}-0.289 \\
\left({ }^{* * *}\right)\end{array}$ \\
\hline LTD & $16.4 \%$ & $13.0 \%$ & $\begin{array}{l}-9.66 \\
(* * *)\end{array}$ & & & & & & & 1 \\
\hline
\end{tabular}

Note: * $p<0.10 ;{ }^{* * *} p<0.01$. "Domestic firms" are firms with fully national share capital; "Foreign firms" are firms with partial or total foreign ownership; EXP = total exports as a percentage of total sales; INT = index of internationalization; $\mathrm{FO}=$ percentage of foreign share capital; INST $=\mathrm{HIEC}_{\text {Portugal }}-\mathrm{HIEC}_{\text {parent }}$ country $\mathrm{ROA}=$ return on assets; $\mathrm{AGE}=$ logarithm of firm age, in years; SIZ = firm size, measured by the logarithm of total assets; STD = current liabilities / total assets; LTD = non-current liabilities/total assets.

In order to attain our research objective, we applied two different econometric techniques. First, a panel data methodology which can be estimated through three different regression models: Pooled Ordinary Least Squares (POLS), Fixed Effects Model (FEM) and Random Effects Model (REM). Applying the Breusch-Pagan and Hausman tests to choose the most appropriate regression technique, the Breusch-Pagan test leads to the rejection of the null hypothesis, indicating that REM is more appropriate than POLS and the Hausman test leads to the acceptance of null hypothesis that REM is preferable to FEM. As stated by Majocchi and Strange (2012), the use of a random effects approach is advisable since there are reasons to believe that not all relevant variables are included in our model, that is, some potential explanatory variables excluded may be constant over time but may vary across firms, while others may be constant across firms but may vary over time. Similarly, Singla et al. (2017), argue that the fixed-effects approach is not appropriate because some of the independent variables are time-invariant for some of the firms and, in addition, the fixed-effects approach may not have produced consistent and efficient estimates for panels over relatively short periods such as the 8-year period of the present study (Chintagunta et al. 1991). In each case, we checked for multi-collinearity and found adequate VIF factors in all regressions. We also controlled for heteroscedasticity using Whites' cross-section method, and hence have robust standard errors. Second, since the dependent variables are left-censored (obviously, there are no values below zero for INT and EXP is defined between zero and one), we adopted a Tobit methodology (Gujarati and Porter 2008). Tobit regressions are nonlinear; therefore, the coefficients should be interpreted with care and do not measure the real causal effect on the dependent variable. This effect is correctly measured only by the marginal effect, however the coefficients maintain the significance and sign of the marginal effects, allowing the testing of our hypotheses.

In the two methodologies, we ran the models with the two dependent variables (EXP and INT) on the variables FO and INST and the control variables profitability (ROA), AGE, SIZ and debt (divided in short-term debt-STD and long-term debt-LTD). The explanatory power of the REM model is given by the overall $R^{2}$ and the significance of the Tobit regression is assessed by reference to the Wald $\chi^{2}$ statistic and the log-likelihood ratio. 


\section{Results}

The regression results for the random-effects model are presented in Table 3, where the two alternative dependent variables are run on the variables "foreign ownership" (FO), "institutional difference" (INST) and development variables (HDI and GDP), and the control variables ROA, AGE, SIZ and debt (STD and LTD). The first column presents the results for all firms considering only the control variables and the second column introduces a dummy variable for foreign-owned firms (DUM_FO). The following columns present separate results for the domestic and foreign firms' sub-samples. With the full specifications the random-effects models present a goodness of fit between $4 \%$ and $12 \%$.

Table 3. Results: Random-effects model.

\begin{tabular}{|c|c|c|c|c|c|c|c|c|c|}
\hline & \multicolumn{2}{|c|}{$\begin{array}{l}\text { All Firms } \\
(\mathrm{n}=5722)\end{array}$} & \multicolumn{2}{|c|}{$\begin{array}{l}\text { Domestic Firms } \\
\quad(n=5453)\end{array}$} & \multicolumn{5}{|c|}{$\begin{array}{l}\text { Foreign Firms } \\
\quad(n=269)\end{array}$} \\
\hline & EXP & EXP & EXP & INT & EXP & EXP & EXP & EXP & INT \\
\hline $\mathrm{C}$ & $\begin{array}{c}-0.229^{* * *} \\
(0.000)\end{array}$ & $\begin{array}{c}-0.226^{* * *} \\
(0.000)\end{array}$ & $\begin{array}{c}-0.245^{* * *} \\
(0.000)\end{array}$ & $\begin{array}{c}-0.340^{* * *} \\
(0.000)\end{array}$ & $\begin{array}{c}0.37 \\
(0.000)\end{array}$ & $\begin{array}{c}0.513 * * * \\
(0.000)\end{array}$ & $\begin{array}{c}0.477^{* * *} \\
(0.000)\end{array}$ & $\begin{array}{c}0.492^{* * *} \\
(0.000)\end{array}$ & $\begin{array}{c}-0.151 \text { * } \\
(0.089)\end{array}$ \\
\hline $\mathrm{FO}$ & & & & & $\begin{array}{l}0.002 * * \\
(0.031)\end{array}$ & & & & \\
\hline DUM_FO & & $\begin{array}{l}0.200 * * * \\
(0.000)\end{array}$ & & & & & & & \\
\hline INST & & & & & & $\begin{array}{c}-0.003 \text { * } \\
(0.099)\end{array}$ & & & $\begin{array}{c}-0.033 \text { ** } \\
(0.012)\end{array}$ \\
\hline HDI & & & & & & & $\begin{array}{c}-0.890 \text { ** } \\
(0.022)\end{array}$ & & \\
\hline GDP & & & & & & & & $\begin{array}{c}-0.000 \text { ** } \\
(0.014)\end{array}$ & \\
\hline \multicolumn{10}{|l|}{ Controls } \\
\hline ROA & $\begin{array}{c}0.110 * * * \\
(0.000)\end{array}$ & $\begin{array}{c}0.112 * * * \\
(0.000)\end{array}$ & $\begin{array}{c}0.113^{* * *} \\
(0.000)\end{array}$ & $\begin{array}{c}-0.029 * \\
(0.053)\end{array}$ & & & & & $\begin{array}{l}-0.023 \\
(0.660)\end{array}$ \\
\hline AGE & $\begin{array}{c}0.045^{* * *} \\
(0.000)\end{array}$ & $\begin{array}{c}0.048^{* * *} \\
(0.000)\end{array}$ & $\begin{array}{c}0.050^{* * *} \\
(0.000)\end{array}$ & $\begin{array}{c}0.033^{* * *} \\
(0.000)\end{array}$ & & & & & $\begin{array}{c}0.075^{* * *} \\
(0.000)\end{array}$ \\
\hline SIZ & $\begin{array}{c}0.049^{* * *} \\
(0.000)\end{array}$ & $\begin{array}{c}0.046^{* * *} \\
(0.000)\end{array}$ & $\begin{array}{c}0.047^{* * * *} \\
(0.000)\end{array}$ & $\begin{array}{c}0.055^{* * * *} \\
(0.000)\end{array}$ & & & & & $\begin{array}{l}0.019^{*} \\
(0.059)\end{array}$ \\
\hline STD & $\begin{array}{c}0.000 \\
(0.974)\end{array}$ & $\begin{array}{c}0.002 \\
(0.974)\end{array}$ & $\begin{array}{c}0.007 \\
(0.335)\end{array}$ & $\begin{array}{c}0.009 \\
(0.256)\end{array}$ & & & & & $\begin{array}{l}-0.031 \\
(0.321)\end{array}$ \\
\hline LTD & $\begin{array}{c}-0.023^{* * *} \\
(0.003)\end{array}$ & $\begin{array}{c}-0.019 * * \\
(0.011)\end{array}$ & $\begin{array}{l}-0.020^{* *} \\
(0.011)\end{array}$ & $\begin{array}{c}-0.031^{* * *} \\
(0.000)\end{array}$ & & & & & $\begin{array}{c}0.004 \\
(0.923)\end{array}$ \\
\hline Overall $R^{2}$ & 0.06 & 0.08 & 0.06 & 0.12 & 0.02 & 0.03 & 0.03 & 0.01 & 0.04 \\
\hline
\end{tabular}

Table 4 presents the regression results for the same dependent variables but with a Tobit specification, with its significance assessed by reference to the Wald $\chi^{2}$ statistic and the log-likelihood ratio. The Tobit regressions show comforting results for the overall indexes of goodness of fit ( $\chi^{2}$ and log-likelihood ratio), suggesting a good overall specification of the model.

One of the objectives of the present paper is to test the presence of non-linear effects of foreign ownership in internationalization. Table 5 presents only the most significant results obtained with the independent variables FO and INST and their squares, for the sub-sample of "foreign firms". 
Table 4. Results: Tobit model.

\begin{tabular}{|c|c|c|c|c|c|c|c|c|c|}
\hline & \multicolumn{2}{|c|}{$\begin{array}{l}\text { All Firms } \\
(\mathrm{n}=5722)\end{array}$} & \multicolumn{2}{|c|}{$\begin{array}{l}\text { Domestic Firms } \\
\quad(n=5453)\end{array}$} & \multicolumn{5}{|c|}{$\begin{array}{l}\text { Foreign Firms } \\
\quad(n=269)\end{array}$} \\
\hline & EXP & INT & EXP & INT & EXP & EXP & EXP & EXP & INT \\
\hline $\mathrm{C}$ & $\begin{array}{c}-0.793^{* * *} \\
(0.000)\end{array}$ & $\begin{array}{c}-1.415^{* * *} \\
(0.000)\end{array}$ & $\begin{array}{c}-0.812^{* * *} \\
(0.000)\end{array}$ & $\begin{array}{c}-1.465^{* * *} \\
(0.000)\end{array}$ & $\begin{array}{c}0.346^{* * *} \\
(0.000)\end{array}$ & $\begin{array}{c}0.470^{* * *} \\
(0.000)\end{array}$ & $\begin{array}{c}0.437^{* * *} \\
(0.000)\end{array}$ & $\begin{array}{c}0.480^{* * *} \\
(0.000)\end{array}$ & $\begin{array}{c}-0.459^{* * *} \\
(0.000)\end{array}$ \\
\hline FO & & & & & $\begin{array}{c}0.002 * * * \\
(0.000)\end{array}$ & & & & \\
\hline INST & & & & & & $\begin{array}{c}-0.009 * * * \\
(0.000)\end{array}$ & & & $\begin{array}{c}-0.006^{* * *} \\
(0.000)\end{array}$ \\
\hline HDI & & & & & & & $\begin{array}{l}-1.422 * * * \\
(0.000)\end{array}$ & & \\
\hline GDP & & & & & & & & $\begin{array}{c}-0.000 \text { ** } \\
(0.000)\end{array}$ & \\
\hline \multicolumn{10}{|l|}{ Controls } \\
\hline ROA & $\begin{array}{c}0.580^{* * *} \\
(0.000)\end{array}$ & $\begin{array}{l}0.088^{* *} \\
(0.022)\end{array}$ & $\begin{array}{c}0.625^{* * *} \\
(0.000)\end{array}$ & $\begin{array}{c}0.116^{* * *} \\
(0.005)\end{array}$ & & & & & $\begin{array}{c}-0.209 * \\
(0.068)\end{array}$ \\
\hline AGE & $\begin{array}{c}-0.011^{* * *} \\
(0.004)\end{array}$ & $\begin{array}{c}0.040 * * * \\
(0.000)\end{array}$ & $\begin{array}{l}-0.001 \\
(0.825)\end{array}$ & $\begin{array}{c}0.040^{* * *} \\
(0.000)\end{array}$ & & & & & $\begin{array}{c}0.055^{* * *} \\
(0.000)\end{array}$ \\
\hline SIZ & $\begin{array}{c}0.123^{* * *} \\
(0.000)\end{array}$ & $\begin{array}{c}0.165^{* * *} \\
(0.000)\end{array}$ & $\begin{array}{c}0.119 * * * \\
(0.000)\end{array}$ & $\begin{array}{c}0.170^{* * *} \\
(0.000)\end{array}$ & & & & & $\begin{array}{c}0.056^{* * *} \\
(0.000)\end{array}$ \\
\hline STD & $\begin{array}{c}0.248^{* * *} \\
(0.000)\end{array}$ & $\begin{array}{c}0.040^{* * *} \\
(0.015)\end{array}$ & $\begin{array}{c}0.269 * * * \\
(0.000)\end{array}$ & $\begin{array}{c}0.049^{* * *} \\
(0.000)\end{array}$ & & & & & $\begin{array}{c}-0.089 * * \\
(0.028)\end{array}$ \\
\hline LTD & $\begin{array}{c}-0.032 \text { ** } \\
(0.026)\end{array}$ & $\begin{array}{c}-0.039^{* * *} \\
(0.009)\end{array}$ & $\begin{array}{l}-0.016 \\
(0.293)\end{array}$ & $\begin{array}{c}-0.033^{* *} \\
(0.035)\end{array}$ & & & & & $\begin{array}{c}-0.088 \\
(0.107)\end{array}$ \\
\hline $\operatorname{LR} \chi^{2}$ & $6215.5^{* * *}$ & $9633.1^{* * *}$ & $5502.2^{* * *}$ & $9183.1^{* * *}$ & $34.2^{* * *}$ & $54.0^{* * *}$ & $60.1^{* * *}$ & $17.6^{* * *}$ & $142.8^{* * *}$ \\
\hline LLR & $-27,009.7$ & $-25,695.3$ & $-25,568.5$ & $-24,506.5$ & -1111.1 & -1097.98 & -1099.0 & -1119.6 & -1074.4 \\
\hline
\end{tabular}

Note: Standard-deviations presented in brackets. ${ }^{*} p<0.10 ;{ }^{* *} p<0.05 ;{ }^{* * *} p<0.01$.

Table 5. Testing the presence of non-linearities (foreign firms: $n=269$ ).

\begin{tabular}{|c|c|c|c|c|c|c|c|c|}
\hline \multicolumn{6}{|c|}{ Tobit } & \multicolumn{3}{|c|}{ Random-Effects } \\
\hline & EXP & EXP & INT & INT & & EXP & EXP & EXP \\
\hline C & $\begin{array}{c}0.387^{* * *} \\
(0.000)\end{array}$ & $\begin{array}{c}0.437^{* * * *} \\
(0.000)\end{array}$ & $\begin{array}{c}0.131^{* * * *} \\
(0.000)\end{array}$ & $\begin{array}{c}0.110^{* * * *} \\
(0.000)\end{array}$ & & $\begin{array}{c}0.460 * * * \\
(0.000)\end{array}$ & $\begin{array}{c}-0.476^{* * *} \\
(0.000)\end{array}$ & $\begin{array}{c}0.231^{* * * *} \\
(0.000)\end{array}$ \\
\hline $\begin{array}{c}\mathrm{FO} \\
\mathrm{FO}^{2}\end{array}$ & & & & & & & & \\
\hline INST & & & $\begin{array}{c}-0.007^{* * *} \\
(0.000)\end{array}$ & & & & & $\begin{array}{c}-0.003 \\
(0.090)\end{array}$ \\
\hline INST $^{2}$ & & & $\begin{array}{c}0.000^{* * *} \\
(0.000)\end{array}$ & & & & & $\begin{array}{c}0.000 \\
(0.237)\end{array}$ \\
\hline HDI & $\begin{array}{c}-1.802 * * * \\
(0.000)\end{array}$ & & & $\begin{array}{c}-0.735^{* * *} \\
(0.000)\end{array}$ & & $\begin{array}{c}-0.950 \text { ** } \\
(0.029)\end{array}$ & & \\
\hline $\mathrm{HDI}^{2}$ & $\begin{array}{c}5.873^{* * *} \\
(0.000)\end{array}$ & & & $\begin{array}{l}5.864^{*} \\
(0.000)\end{array}$ & & $\begin{array}{c}2.671 \\
(0.162)\end{array}$ & & \\
\hline GDP & & $\begin{array}{c}-0.000^{* * *} \\
(0.000)\end{array}$ & & & & & $\begin{array}{c}-5.010 * * * \\
(0.018)\end{array}$ & \\
\hline $\mathrm{GDP}^{2}$ & & $\begin{array}{c}-0.000^{* * *} \\
(0.000)\end{array}$ & & & & & $\begin{array}{l}0.000 * \\
(0.100)\end{array}$ & \\
\hline $\begin{array}{c}\text { LR } \chi^{2} \\
\text { LLR }\end{array}$ & $\begin{array}{l}76.68^{* * *} \\
-1085.8\end{array}$ & $\begin{array}{c}1541.4^{* * *} \\
-1089.8\end{array}$ & $\begin{array}{l}82.9^{* * *} \\
-1117.3\end{array}$ & $\begin{array}{l}35.0 * * * \\
-1129.1\end{array}$ & Overall $R^{2}$ & $4 \%$ & $2 \%$ & $3 \%$ \\
\hline
\end{tabular}

Notes: Standard-deviations presented in brackets. ${ }^{*} p<0.10 ;{ }^{* *} p<0.05 ;{ }^{* * *} p<0.01$.

Finally, following the Eurostat approach, our sample is clustered in four groups according to technological intensity: low technology-NACE codes 10 to 18 and 31 to 32 (56.5\% of the sample); medium-low technology-22 to 25 (31.4\%); medium-high technology$19 / 20 / 21$ and 27 to $30(11.6 \%)$; high technology-26 (0.5\%). These four groups of firms are 
rather similar in terms of average firm age, size and export activity, albeit foreign capital is much more prevalent in the medium-high and high technology groups. Table 6 presents the results of a Tobit model applied to those four different groups of firms.

Table 6. Results for all firms divided according to technological intensity (Tobit model).

\begin{tabular}{|c|c|c|c|c|c|c|c|c|}
\hline \multirow[b]{3}{*}{$\mathrm{C}$} & \multicolumn{4}{|c|}{ Group I $(n=3231)$} & \multicolumn{4}{|c|}{ Group II $(n=1799)$} \\
\hline & \multicolumn{2}{|c|}{ EXP } & \multicolumn{2}{|c|}{ INT } & \multicolumn{2}{|c|}{ EXP } & \multicolumn{2}{|c|}{ INT } \\
\hline & $\begin{array}{c}-0.845^{* * *} \\
(0.025)\end{array}$ & $\begin{array}{c}-0.862 * * * \\
(0.025)\end{array}$ & $\begin{array}{c}-1.444^{* * *} \\
(0.026)\end{array}$ & $\begin{array}{c}-1.435^{* * *} \\
(0.026)\end{array}$ & $\begin{array}{c}-0.657^{* * *} \\
(0.031)\end{array}$ & $\begin{array}{c}-0.675^{* * *} \\
(0.030)\end{array}$ & $\begin{array}{c}-1.448^{* * *} \\
(0.039)\end{array}$ & $\begin{array}{c}1.451^{* * *} \\
(0.039)\end{array}$ \\
\hline $\mathrm{FO}$ & $\begin{array}{c}0.002^{* * *} \\
(0.000)\end{array}$ & & $\begin{array}{c}-0.001 * * * \\
(0.000)\end{array}$ & & $\begin{array}{c}0.003^{* * *} \\
(0.000)\end{array}$ & & $\begin{array}{c}0.001^{* * *} \\
(0.000)\end{array}$ & \\
\hline INST & & $\begin{array}{c}-0.009 * * * \\
(0.002)\end{array}$ & & $\begin{array}{c}0.001 \\
(0.002)\end{array}$ & & $\begin{array}{c}-0.021 * * * \\
(0.002)\end{array}$ & & $\begin{array}{c}-0.009 * * * \\
(0.002)\end{array}$ \\
\hline \multicolumn{9}{|l|}{ Controls } \\
\hline ROA & $\begin{array}{c}0.634^{* * * *} \\
(0.056)\end{array}$ & $\begin{array}{c}0.627^{* * *} \\
(0.056)\end{array}$ & $\begin{array}{l}0.109^{* *} \\
(0.052)\end{array}$ & $\begin{array}{l}0.111 * * \\
(0.052)\end{array}$ & $\begin{array}{c}0.497^{* * * *} \\
(0.062)\end{array}$ & $\begin{array}{c}0.490 * * * \\
(0.062)\end{array}$ & $\begin{array}{c}0.089 \\
(0.073)\end{array}$ & $\begin{array}{c}0.086 \\
(0.073)\end{array}$ \\
\hline AGE & $\begin{array}{l}-0.001 \\
(0.005)\end{array}$ & $\begin{array}{l}-0.003 \\
(0.005)\end{array}$ & $\begin{array}{c}0.023^{* * * *} \\
(0.006)\end{array}$ & $\begin{array}{c}0.024^{* * *} \\
(0.006)\end{array}$ & $\begin{array}{l}-0.005 \\
(0.007)\end{array}$ & $\begin{array}{l}-0.009 \\
(0.007)\end{array}$ & $\begin{array}{c}0.076^{* * *} \\
(0.009)\end{array}$ & $\begin{array}{c}0.075^{* * *} \\
(0.008)\end{array}$ \\
\hline SIZ & $\begin{array}{c}0.119 * * * \\
(0.002)\end{array}$ & $\begin{array}{c}0.123^{* * *} \\
(0.002)\end{array}$ & $\begin{array}{c}0.172 * * * \\
(0.003)\end{array}$ & $\begin{array}{c}0.170 * * * \\
(0.002)\end{array}$ & $\begin{array}{c}0.104^{* * *} \\
(0.003)\end{array}$ & $\begin{array}{c}0.109 * * * \\
(0.003)\end{array}$ & $\begin{array}{c}0.156^{* * *} \\
(0.004)\end{array}$ & $\begin{array}{c}0.157^{* * *} \\
(0.004)\end{array}$ \\
\hline STD & $\begin{array}{c}0.330 * * * \\
(0.017)\end{array}$ & $\begin{array}{c}0.328^{* * *} \\
(0.017)\end{array}$ & $\begin{array}{c}0.054^{* * *} \\
(0.016)\end{array}$ & $\begin{array}{c}0.055^{* * *} \\
(0.016)\end{array}$ & $\begin{array}{c}0.173^{* * *} \\
(0.019)\end{array}$ & $\begin{array}{c}0.172^{* * *} \\
(0.019)\end{array}$ & $\begin{array}{c}0.000 \\
(0.024)\end{array}$ & $\begin{array}{c}0.001 \\
(0.024)\end{array}$ \\
\hline LTD & $\begin{array}{c}-0.070^{* * *} \\
(0.020)\end{array}$ & $\begin{array}{c}-0.075^{* * *} \\
(0.020)\end{array}$ & $\begin{array}{c}-0.042^{* *} \\
(0.019)\end{array}$ & $\begin{array}{c}-0.039^{* *} \\
(0.019)\end{array}$ & $\begin{array}{l}0.057^{* *} \\
(0.022)\end{array}$ & $\begin{array}{l}0.039 * \\
(0.022)\end{array}$ & $\begin{array}{l}-0.044 \\
(0.029)\end{array}$ & $\begin{array}{c}-0.049 \text { * } \\
(0.029)\end{array}$ \\
\hline $\operatorname{LR} \chi^{2}$ & $3716.1^{* * *}$ & $3650.8^{* * *}$ & $5782.9^{* * *}$ & $5757.0 * * *$ & $1867.8^{* * *}$ & $1726.4^{* * *}$ & $2544.9^{* * *}$ & $2545.2^{* * *}$ \\
\hline \multirow[t]{3}{*}{ LLR } & $-16,033.4$ & $-16,066.1$ & $-13,822.2$ & $-13,831.1$ & -7549.4 & -7609.1 & -8535.7 & -8537.0 \\
\hline & \multicolumn{4}{|c|}{ Group III $(n=665)$} & \multicolumn{4}{|c|}{ Group IV $(n=27)$} \\
\hline & \multicolumn{2}{|c|}{ EXP } & \multicolumn{2}{|c|}{ INT } & \multicolumn{2}{|c|}{ EXP } & \multicolumn{2}{|c|}{ INT } \\
\hline $\mathrm{FO}$ & $\begin{array}{c}-0.639 * * * \\
(0.047) \\
0.002 * * * \\
(0.000)\end{array}$ & $\begin{array}{c}-0.629^{* * *} \\
(0.046)\end{array}$ & $\begin{array}{c}-1.091 \text { *** } \\
(0.054) \\
-0.000 \\
(0.000)\end{array}$ & $\begin{array}{c}-1.078^{* * *} \\
(0.054)\end{array}$ & $\begin{array}{c}-0.195 \\
(0.404) \\
-0.011^{* * *} \\
(0.003)\end{array}$ & $\begin{array}{l}-0.161 \\
(0.397)\end{array}$ & $\begin{array}{c}0.859 * \\
(0.478) \\
0.008 \\
(0.008)\end{array}$ & $\begin{array}{l}0.923 * \\
(0.471)\end{array}$ \\
\hline INST & & $\begin{array}{c}-0.018^{* * *} \\
(0.002)\end{array}$ & & $\begin{array}{c}-0.003 * \\
(0.002)\end{array}$ & & $\begin{array}{c}0.058^{* * *} \\
(0.014)\end{array}$ & & $\begin{array}{c}-0.068^{* *} \\
(0.034)\end{array}$ \\
\hline \multicolumn{9}{|l|}{ Controls } \\
\hline ROA & $\begin{array}{c}0.509 * * * \\
(0.086)\end{array}$ & $\begin{array}{c}0.490 * * * \\
(0.085)\end{array}$ & $\begin{array}{l}-0.006 \\
(0.091)\end{array}$ & $\begin{array}{l}-0.008 \\
(0.091)\end{array}$ & $\begin{array}{l}-0.014 \\
(0.271)\end{array}$ & $\begin{array}{l}-0.004 \\
(0.272)\end{array}$ & $\begin{array}{l}-0.375 \\
(0.448)\end{array}$ & $\begin{array}{l}-0.341 \\
(0.446)\end{array}$ \\
\hline AGE & $\begin{array}{c}-0.021 \\
(0.010)\end{array}$ & $\begin{array}{c}-0.025^{* *} \\
(0.010)\end{array}$ & $\begin{array}{c}0.044^{* * *} \\
(0.011)\end{array}$ & $\begin{array}{c}0.048^{* * *} \\
(0.011)\end{array}$ & $\begin{array}{l}-0.044 \\
(0.043)\end{array}$ & $\begin{array}{l}-0.045 \\
(0.043)\end{array}$ & $\begin{array}{c}-0.123 \text { ** } \\
(0.060)\end{array}$ & $\begin{array}{c}-0.123^{* *} \\
(0.060)\end{array}$ \\
\hline SIZ & $\begin{array}{c}0.116^{* * *} \\
(0.005)\end{array}$ & $\begin{array}{c}0.117^{* * *} \\
(0.005)\end{array}$ & $\begin{array}{c}0.131^{* * *} \\
(0.005)\end{array}$ & $\begin{array}{c}0.127^{* * *} \\
(0.005)\end{array}$ & $\begin{array}{c}0.069 \\
(0.051)\end{array}$ & $\begin{array}{c}0.064 \\
(0.049)\end{array}$ & $\begin{array}{l}-0.070 \\
(0.065)\end{array}$ & $\begin{array}{l}-0.080 \\
(0.064)\end{array}$ \\
\hline STD & $\begin{array}{c}0.113^{* * *} \\
(0.028)\end{array}$ & $\begin{array}{c}0.117^{* * *} \\
(0.028)\end{array}$ & $\begin{array}{c}0.101^{* * *} \\
(0.032)\end{array}$ & $\begin{array}{c}0.105^{* * *} \\
(0.032)\end{array}$ & $\begin{array}{c}-0.090 \\
(0.119)\end{array}$ & $\begin{array}{l}-0.087 \\
(0.119)\end{array}$ & $\begin{array}{c}-0.342 * \\
(0.178)\end{array}$ & $\begin{array}{c}-0.329 * \\
(0.177)\end{array}$ \\
\hline LTD & $\begin{array}{c}0.139 * * * \\
(0.037)\end{array}$ & $\begin{array}{c}0.125^{* * *} \\
(0.037)\end{array}$ & $\begin{array}{l}0.068 * \\
(0.040)\end{array}$ & $\begin{array}{l}0.079 * * \\
(0.040)\end{array}$ & $\begin{array}{c}0.625^{* * *} \\
(0.146)\end{array}$ & $\begin{array}{c}0.631^{* * *} \\
(0.146)\end{array}$ & $\begin{array}{l}-0.054 \\
(0.228)\end{array}$ & $\begin{array}{l}-0.057 \\
(0.229)\end{array}$ \\
\hline $\operatorname{LR} \chi^{2}$ & $1034.6^{* * *}$ & $1194.6^{* * *}$ & $794.8^{* * *}$ & $802.4^{* * *}$ & $53.5^{* * *}$ & $43.8^{* * *}$ & 10.4 & $13.7^{* *}$ \\
\hline LLR & -2359.0 & -2340.8 & -2971.4 & -2971.4 & -117.1 & -117.3 & -134.3 & -133.5 \\
\hline
\end{tabular}

Notes: low technology (Group I)-NACE codes 10 to 18 and 31 to 32; medium-low technology (Group II)—22 to 25; medium-high technology (Group III) - 19/20/21 and 27 to 30; high technology (Group IV) -26 Standarddeviations presented in brackets. ${ }^{*} p<0.10$; ${ }^{* *} p<0.05 ;{ }^{* * *} p<0.01$.

\section{Discussion}

We now examine our results confronting them with the different hypotheses. The first rows in Tables 3 and 4 evidence that "foreign ownership" does seem to have a significant positive impact on internationalization. This evidence that foreign-owned firms display higher levels of internationalization is in line with the results reported by 
Cerrato and Piva (2012) and Wach (2017), implying that foreign firms have a clearer focus on international markets, being helpful their international experience and possibly taking advantage of the resources available in Portugal. The presence of a foreign shareholder can be an important source of knowledge of foreign markets, international experience and business contacts, therefore positively affecting internationalization. Thus, any changes in the ownership structure of firms should also be evaluated in the light of the possible effects on their international expansion. Considering only the wholly or partially foreign-owned firms, regressions using the "distance" variables evidence that firms with capital coming from more institutionally and economically advanced countries display higher levels of export intensity and diversity (with more significant results regarding export intensity).

Furthermore, regarding the possibility of a non-linear relationship, the results in Table 5 evidence that institutional difference presents a significant U-shaped relation with international diversification (regarding the Tobit specification that non-linear relation with export intensity and diversification is also significant when considering the differences in terms of HDI). Firms with foreign capital coming from more institutionally advanced countries (lower levels for INST) display increased levels of exports and international diversification. Partially confirming H2, this result evidences the potential low internationalization levels for firms where a part or the whole of the capital comes from less developed economies, possibly because they may lack the resources, technologies and managerial and international networking skills necessary to enhance internationalization. Additionally, we could posit the hypothesis that cultural (and economic) distance, in absolute terms, has a positive effect in internationalization, a result deserving further research.

The non-linear relationship between institutional differences and internationalization calls for major attention to those effects by policymakers, whom should focus their energies in attracting FDI from significantly more developed countries, enhancing the internationalization levels and their spillover effects to the economy. Capital coming from less-developed countries also seems to have a positive effect, possibly due to some sort of positive "cultural" effects. Globally, these results mean that when capital comes from countries similar to Portugal in terms of institutional/cultural development levels, the impacts on internationalization are lower, possible because that capital is mainly spent on promoting the exploitation of the company's own domestic market.

Regarding the hypotheses associated with the control variables (Tables 3 and 4), the coefficients tend to be significant, confirming hypotheses H3 to H6. Profitability seems to exert a positive effect on export intensity, confirming H3 and evidencing that firm profitability and liquidity generation is an important factor for a stronger internationalization. Confirming H4, a firm's age seems to have a positive impact on the degree of internationalization when measured by either export intensity or the entropy index of international diversification. Possibly, older firms are more likely to be in the maturity phase, with well-established export markets and international ties. Smaller firms present lower internationalization levels, possibly a result of their lack of resources and difficulties with access to finance and specific skills, confirming H5 and the results of Cerrato and Piva (2012) for Italian SMEs. Typically, Portuguese firms are micro or small firms, so policymakers should build an adequate set of incentives to promote mergers and acquisitions, as a way to enhance firms' internationalization. Finally, confirming previous results and H6, more leveraged firms display lower levels of internationalization, but short-term debt exerts a positive effect, thus evidencing the immediate financing needs faced by firms trying to expand internationally. This result is typically found in the literature and is in line with the predictions of the agency and pecking order theories, since a high level of leverage imposes a fixed financial commitment on the firm, reducing the free cash flows available to management (Vieira 2017).

Regarding differences between industries, here classified according to their technological content, evidences that with the exception of Group IV (high-technology firms) foreign capital seems to exert a positive effect on export intensity across sectors, with the results for international diversification being less significant. Institutional differences continue to 
present a significant negative coefficient, particularly when considering export intensity as the dependent variable. These results highlight the fact that industry characteristics could matter in SMEs' internationalization processes.

The generalization of our results should be considered carefully. Internationalization can be both an "inward" and "outward" process (Welch and Luostarinen 1993). As stressed by Cerrato and Piva (2012), many SMEs may start going international in terms of inward (importing) rather than outward (exporting) activities. Importing activities and experience may then have positive effects on exports. Future research might also incorporate other dimensions of internationalization, such as the use of alliances and foreign direct investments, in order to extend the generalization of our findings. In the current competitive environment, internationalization is no longer expressed only in terms of sales and resources located abroad, but also in terms of the firm's (and the entrepreneur's) alliances and network relationships. As is highlighted by network-based contributions (Johanson and Vahlne 2009), internationalization can be assessed as internationalization of the network in which the firm is embedded. Therefore, the inclusion of variables related to the firm's "networking activity" could lead to a deeper understanding of its patterns of international development.

Singla et al. (2017) argue that foreign corporates have resources such as knowledge about foreign markets and connections that are part of their established global networks. So, foreign firms tend to have the requisite monitoring skills, and their positive impact on exports is indicative of the advantages of cooperating with these investors in order to establish a foothold in foreign markets. As SMEs in Portugal face increasing competition, joining hands with resource-rich investors such as foreign corporations and institutional investors would be a fruitful strategy to enhance the international competitiveness of Portuguese firms.

\section{Conclusions}

Management theories should not consider firms just as a value-maximizing entity regardless of its owners. Different owners and managers have different attitudes towards risk, face different incentives and bring to the firm different resources, so apparently similar firms could present significant differences in terms of internationalization. Some recent papers have compared performance between foreign-owned and domestic-owned firms. While some of those studies have found that foreign-owned firms outperform their domestic counterparts, other studies evidenced the opposite. Nevertheless, only a limited number of studies examined how the degree of foreign ownership in a firm influences its international performance.

In the context of the current literature about foreign investment effects and ownership and control advantages, this paper fills a gap studying the differences in terms of internationalization between domestic and wholly or partially owned foreign firms.

The degree of foreign ownership and institutional difference generally evidenced a significant positive relation with internationalization, implying that the origin of the capital seems to exert influence on the different firms' internationalization levels. Additionally, in spite of the small coefficients obtained, there seems to exist a non-linear relation between the development level of the country of origin of the capital and internationalization, where firms with share capital coming from more institutionally advanced countries attain higher levels of internationalization.

Regarding the main questions addressed in this paper, we can answer that: (i) compared to other firms, foreign-owned firms display higher internationalization levels; (ii) internationalization is positively impacted when foreign capital comes from more institutionally and economically advanced countries; (iii) there is a significant positive relation between firm's profitability, age and size with internationalization and a significant negative impact of the firms' level of indebtedness on internationalization.

This paper contributes to the literature about the impact of foreign capital on internationalization, studying if there are significant differences between domestic and 
foreign-owned firms in terms of internationalization. Nevertheless, some limitations of the paper should be mentioned (i) Firstly, the firms' degree of internationalization is affected by other variables that were not considered (e.g., managerial labor and product markets, political and economic factors or even the personality of managers and shareholders), so the results should be treated with caution. Notice that the results evidence internationalization differences between the two types of firms, but we do not fully account for the complexity of interests that are involved in an ownership structure. Possibly, considering internal factors such as knowledge transfer, R\&D, product positioning and marketing, it would be possible to unveil the differing impacts on firm internationalization. (ii) Secondly, firms may use other internationalization methods that have not been explored. The majority of the firms in the sample are too small to have foreign subsidiaries, but they could have entered into agreements with local companies. Unfortunately, the database does not provide that information. Future extensions of this work could analyze the use of alliances between the exporter SMEs and local partners. In the same way, it would be useful to explore the relationship between the international involvement of SMEs and the financial results obtained by these policies. (iii) Thirdly, the dataset comprises 5722 firms, but only 269 have partial or total foreign ownership. Ideally, a larger number of observations and firms, in particular of "foreign firms", allowing a clearer differentiation between wholly foreign-owned firms and JVs, could yield more robust results. Future research could explore the relationship of different types of owners with internationalization in greater detail, because different types of owners have varying preferences and motivations with respect to firm's internationalization (Tihanyi et al. 2003). Future research could investigate the specific objectives of foreign capital entry into each firm. In this sense, it is necessary to assess whether foreign entry is associated with a long-term view, focused on firm growth and expansion abroad, or is it simply a speculative short-term move? (iv) The potential endogeneity in the relation between foreign ownership and internationalization could be addressed in future studies employing alternative methods such as propensity score matching or system GMM. (v) Finally, two factors that can limit the generalization of the results are the measures of internationalization used in the paper and their application to a sample of Portuguese SMEs. Notice that the specific problems faced by firms are heavily dependent on the prevailing institutional and governance environment present in the country (Singh and Gaur 2013).

Given the relevance of the performance-promoting channel of FDI, particularly when assuming the form of JVs, our findings may be useful in the design of investment promotion policies. In particular, our results underline the importance of commercial diplomacy efforts made by policymakers to attract foreign capital, potentially under the form of JVs that promote the establishment of international partnerships between domestic firms and firms located in more developed economies.

Author Contributions: Conceptualization, L.P. and C.L.; methodology, L.P. and I.M.; software, I.M.; validation, L.P.; formal analysis, L.P.; writing, L.P., C.L. and I.M.; supervision, L.P.; project administration and funding acquisition, C.L. All authors have read and agreed to the published version of the manuscript.

Funding: This work is supported by FEDER funds from COMPETE 2020 and Portuguese funds - PORTUGAL 2020. Project IEcPBI-Interactive Ecosystem for Portuguese Business InternationalizationPOCI-01-0145-FEDER-032139.

Institutional Review Board Statement: Not applicable.

Informed Consent Statement: Not applicable.

Data Availability Statement: Not applicable.

Conflicts of Interest: The authors declare no conflict of interest. 


\section{References}

Anand, Jaideep, and Andrew Delios. 1996. Competing globally: How Japanese MNCs have matched goals and strategies in India and China. Columbia Journal of World Business 31: 50-62. [CrossRef]

Anil, Ibrahim, Ekrem Tatoglu, and Gaye Ozkasap. 2014. Ownership and market entry mode choices of emerging country multinationals in a transition country: Evidence from Turkish multinationals in Romania. JEEMS Journal of East European Management Studies 19: 413-52. [CrossRef]

Barber, Brad, and John Lyon. 1996. Detecting abnormal operating performance: The empirical power and specification of test statistics. Journal of Financial Economics 41: 359-99. [CrossRef]

Barney, Jay. 1991. Firm resources and sustained competitive advantage. Journal of Management 17: 99-120. [CrossRef]

Bell, Jim, Dave Crick, and Stephen Young. 2004. Small firm internationalization and business strategy: An exploratory study of 'knowledge-intensive' and 'traditional' manufacturing firms in the UK. International Small Business Journal 22: 23-56. [CrossRef]

Bhaumik, Sumon, Nigel Driffield, and Sarmistha Pal. 2010. Does ownership structure of emerging-market firms affect their outward FDI? The case of the Indian automotive and pharmaceutical sectors. Journal of International Business Studies 41: 437-50. [CrossRef]

Blomström, Magnus, and Fredik Sjöholm. 1999. Technology transfers and spillovers: Does local participation with multinationals matter? European Economic Review 43: 915-23. [CrossRef]

Boehe, Dirk, and Alfredo Jiménez. 2016. How does the geographic export-diversification-performance relationship vary at different levels of export intensity? International Business Review 25: 1262-72. [CrossRef]

Boyd, Brian, and Angelo Solarino. 2016. Ownership of corporations: A review, synthesis, and research agenda. Journal of Management 42: 1282-314. [CrossRef]

Buckley, Peter, and Mark Casson. 1976. The Future of the Multinational Enterprise. Basingstoke: Macmillan.

Caves, Richard. 2007. Multinational Enterprise and Economic Analysis, 3rd ed. Cambridge: Cambridge University Press.

Cerrato, Daniele, and Maria Cristina Piva. 2012. The internationalization of small and medium-sized enterprises: The effect of family management, human capital and foreign ownership. Journal of Management E Governance 16: 617-44.

Chari, Murali, and Ibrahim Shaikh. 2017. Defying distance? Cross border acquisitions by emerging economy firms. Thunderbird International Business Review 59: 173-86. [CrossRef]

Chhibber, Pradeep, and Sumit Majumdar. 2005. Property rights and the control of strategy: Foreign ownership rules and domestic firm globalization in Indian industry. Law \& Policy 27: 52-80.

Chintagunta, Pradeep, Dipak Jain, and Naufel Vilcassim. 1991. Investigating heterogeneity in brand preferences in logit models for panel data. Journal of Marketing Research 28: 417-28. [CrossRef]

Demsetz, Harold, and Belén Villalonga. 2001. Ownership structure and corporate performance. Journal of Corporate Finance 7: 209-33. [CrossRef]

Dhanaraj, Charles, and Paul Beamish. 2003. A resource-based approach to the study of export performance. Journal of Small Business Management 41: 242-61. [CrossRef]

Dimelis, Sophia, and Helen Louri. 2002. Foreign ownership and production efficiency: A quantile regression analysis. Oxford Economic Papers 54: 449-69. [CrossRef]

Douma, Sytse, Rejie George, and Rezaul Kabir. 2006. Foreign and domestic ownership, business groups, and firm performance: Evidence from a large emerging market. Strategic Management Journal 27: 637-57. [CrossRef]

Dunning, John. 1980. Towards an eclectic theory of international production: Some empirical tests. Journal of International Business Studies 11: 9-31. [CrossRef]

Fernández, Zulima, and Mária Nieto. 2006. Impact of ownership on the international involvement of SMEs. Journal of International Business Studies 37: 340-51. [CrossRef]

Fernandez-Ortiz, Rubén, and Guadalupe Lombardo. 2009. Influence of the capacities of top management on the internationalization of SMEs. Entrepreneurship and Regional Development 21: 131-54. [CrossRef]

Filatotchev, Igor, Roger Strange, Jenifer Piesse, and Yung-Chih Lien. 2007. FDI by firms from newly industrialised economies in emerging markets: Corporate governance, entry mode and location. Journal of International Business Studies 38: 556-72. [CrossRef]

Gande, Amar, Christoph Schenzler, and Lemma Senbet. 2009. Valuation effects of global diversification. Journal of International Business Studies 40: 1515-32. [CrossRef]

Gaur, Ajai, and Andrew Delios. 2015. International diversification of emerging market firms: The role of ownership structure and group affiliation. Management International Review 55: 235-53. [CrossRef]

Gedajlovic, Eric, and Daniel Shapiro. 1998. Management and ownership effects: Evidence from five countries. Strategic Management Journal 19: 533-53. [CrossRef]

George, Gerard, Johan Wiklund, and Shaker Zahra. 2005. Ownership and the internationalization of small firms. Journal of Management 31: 210-33. [CrossRef]

Girma, Sourafel, and Holger Görg. 2007. Evaluating the foreign ownership wage premium using a difference-in-differences matching approach. Journal of International Economics 72: 97-112. [CrossRef]

Graves, Chris, and Jill Thomas. 2004. Internationalisation of the family business: A longitudinal perspective. International Journal of Globalisation and Small Business 1: 7-27. [CrossRef]

Greenaway, David, Alessandra Guariglia, and Zhihong Yu. 2014. The more the better? Foreign ownership and corporate performance in China. The European Journal of Finance 20: 681-702. [CrossRef] 
Gujarati, Damodar, and Dawn Porter. 2008. Basic Econometrics, 5th ed. Irwin: McGraw-Hill.

Halkos, George, and Nickloaos Tzeremes. 2010. The effect of foreign ownership on SMEs performance: An efficiency analysis perspective. Journal of Production Analysis 34: 167-80. [CrossRef]

Harris, Richard, and Catherine Robinson. 2003. Foreign ownership and productivity in the United Kingdom: Estimates for UK manufacturing using the ARD. Review of Industrial Organization 22: 207-23. [CrossRef]

Himmelberg, Charles, Glenn Hubbard, and Darios Palia. 1999. Understanding the determinants of managerial ownership and the link between ownership and performance. Journal of Financial Economics 53: 353-84. [CrossRef]

Hintosova, Aneta, and Zuzana Kubikova. 2016. The effect of the degree of foreign ownership on firms' performance. Review of Economic Perspectives 16: 29-43. [CrossRef]

Hitt, Michael, Laszlo Tihanyi, Toyah Miller, and Brian Connelly. 2006. International diversification: Antecedents, outcomes, and moderators. Journal of Management 32: 831-67. [CrossRef]

Holmes, Kim, Edwin Feulner, and Mary O'Grady. 2008. Index of Economic Freedom: The Link between Economic Opportunity and Prosperity. Washington, DC: The Heritage Foundation and The Wall Street Journal.

Hoskisson, Robert, Michael Hitt, Richard Johnson, and Wayne Grossman. 2002. Conflicting voices: The effects of institutional ownership heterogeneity and internal governance on corporate innovation strategies. Academy of Management Journal 45: 697-716.

INE. 2018. Estatísticas da Globalização. Lisboa: Instituto Nacional de Estatística.

Jensen, Michael, and William Meckling. 1976. Theory of the firm: Managerial behavior, agency costs and ownership structure. Journal of Financial Economics 3: 305-60. [CrossRef]

Joh, Sung. 2003. Corporate governance and firm profitability: Evidence from Korea before the economic crisis. Journal of Financial Economics 68: 287-322. [CrossRef]

Johanson, Jan, and Finn Wiedersheim-Paul. 1975. The internationalization of the firm-Four Swedish cases. Journal of Management Studies 12: 305-23. [CrossRef]

Johanson, Jan, and Jan-Erik Vahlne. 1977. The internationalization process of the firm: A model of knowledge development and increasing foreign market commitments. Journal of International Business Studies 8: 23-32. [CrossRef]

Johanson, Jan, and Jan-Erik Vahlne. 2009. The Uppsala internationalization process model revisited: From liability of foreignness to liability of outsidership. Journal of International Business Studies 40: 1411-31. [CrossRef]

Kim, Chan. 1989. Developing a global diversification measure. Management Science 35: 376-83. [CrossRef]

Konings, Jozef. 2001. The effects of foreign direct investment on domestic firms. Economics of Transition 9: 619-33. [CrossRef]

Kontinen, Tanja, and Arto Ojala. 2010. The internationalization of family businesses: A review of extant research. Journal of Family Business Strategy 1: 97-107. [CrossRef]

Kontinen, Tanja, and Arto Ojala. 2011. International opportunity recognition among small and medium-sized family firms. Journal of Small Business Management 49: 490-514. [CrossRef]

Kwok, Chuck, and David Reeb. 2000. Internationalization and firm risk: An upstream-downstream hypothesis. Journal of International Business Studies 31: 611-29. [CrossRef]

Larimo, Jorma, and Ahmad Arslan. 2013. Determinants of foreign direct investment ownership mode choice: Evidence from Nordic investments in Central and Eastern Europe. Journal for East European Management Studies 18: 232-63. [CrossRef]

Leonidou, Leonidas. 2004. An analysis of the barriers hindering small business export development. Journal of Small Business Management 42: 279-302. [CrossRef]

Leonidou, Leonidas, Constantine Katsikeas, Dayananda Palihawadana, and Stavroula Spyropoulu. 2007. An analytical review of the factors stimulating smaller firms to export. International Marketing Review 24: 735-70. [CrossRef]

Liesch, Peter, and Gary Knight. 1999. Information internationalization and hurdle rates in small and medium enterprise internationalization. Journal of International Business Studies 30: 383-94. [CrossRef]

Lin, Wen-Ting. 2012. Family ownership and internationalization processes: Internationalization pace, internationalization scope, and internationalization rhythm. European Management Journal 30: 47-56. [CrossRef]

Lu, Jane, and Paul Beamish. 2001. The internationalization and performance of SMEs. Strategic Management Journal 22: 565-86. [CrossRef]

Lu, Jiangyong, Bin $\mathrm{Xu}$, and Xiaohui Liu. 2009. The effects of corporate governance and institutional environments on export behaviour in emerging economies. Management International Review 49: 455-78. [CrossRef]

Majocchi, Antonio, and Roger Strange. 2012. International diversification: The impact of ownership structure, the market for corporate control and board independence. Management International Review 52: 879-900. [CrossRef]

Manolova, Tatiana, Candida Brush, Linda Edelman, and Patricia Greene. 2002. Internationalization of small firms: Personal factors revisited. International Small Business Journal 20: 9-31. [CrossRef]

Morck, Randall, Andrei Shleifer, and Robert Vishny. 1990. Do managerial objectives drive bad acquisitions? The Journal of Finance 45: 31-48. [CrossRef]

Narayanan, Vijay. 2015. Export barriers for small and medium-sized enterprises: A literature review based on Leonidou's Model. Entrepreneurial Business and Economics Review 3: 105-23. [CrossRef]

Pacheco, Luís. 2017. Financial structure effects on export intensity and diversification: The case of Portuguese industrial firms. International Journal of Globalisation and Small Business 9: 252-76. [CrossRef] 
Pedersen, Torben, and Bent Petersen. 1998. Explaining gradually increasing resource commitment to a foreign market. International Business Review 7: 483-501. [CrossRef]

Ramaswamy, Kannan, Mingfang Li, and Rajaram Veliyath. 2002. Variations in ownership behavior and propensity to diversify: A study of the Indian corporate context. Strategic Management Journal 23: 345-58. [CrossRef]

Rocco, Vincent. 1996. Going global: A CEO's perspective. Journal of Management in Engineering 12: 21-24. [CrossRef]

Ruzzier, Mitja, Robert Hisrich, and Bostjan Antoncic. 2006. SME internationalization research: Past, present, and future. Journal of Small Business and Enterprise Development 13: 476-97. [CrossRef]

Sciascia, Salvatore, Pietro Mazzola, Joseph Astrachan, and Torsten Pieper. 2012. The role of family ownership in international entrepreneurship: Exploring nonlinear effects. Small Business Economics 38: 15-31. [CrossRef]

Shleifer, Andrei, and Robert Vishny. 1997. A survey of corporate governance. The Journal of Finance 52: 737-83. [CrossRef]

Singh, Deeksha, and Ajai Gaur. 2013. Governance structure, innovation and internationalization: Evidence from India. Journal of International Management 19: 300-9. [CrossRef]

Singla, Chitra, Rejie George, and Rajaram Veliyath. 2017. Ownership structure and internationalization of Indian firms. Journal of Business Research 81: 130-43. [CrossRef]

Sommer, Lutz. 2010. Internationalization processes of small-and medium-sized enterprises-A matter of attitude? Journal of International Entrepreneurship 8: 288-317. [CrossRef]

Sousa, Carlos, Francisco Martínez-López, and Filipe Coelho. 2008. The determinants of export performance: A review of the research in the literature between 1998 and 2005. International Journal of Management Reviews 10: 343-74. [CrossRef]

Stouraitis, Vassilios, Mior Mior Harun, and Markus Kyritsis. 2017. Motivators of SME initial export choice and the European Union regional effect in manufacturing. International Journal of Entrepreneurial Behavior \& Research 23: 35-55.

Temouri, Yama, Nigel Driffield, and Anon Dolores Higon. 2008. Analysis of productivity differences among foreign and domestic firms: Evidence from Germany. Review of World Economics 144: 32-54. [CrossRef]

Thomsen, Steen, and Torben Pedersen. 2000. Ownership structure and economic performance in the largest European companies. Strategic Management Journal 21: 689-705. [CrossRef]

Tihanyi, Laszlo, Richard Johnson, Robert Hoskisson, and Michael Hitt. 2003. Institutional ownership differences and international diversification: The effects of boards of directors and technological opportunity. Academy of Management Journal 46: $195-211$.

Venkatraman, Venkat, and Vasudevan Ramanujam. 1986. Measurement of business performance in strategy research: A comparison of approaches. Academy of Management Review 11: 801-14. [CrossRef]

Vieira, Elisabete. 2017. Debt policy and firm performance of family firms: The impact of economic adversity. International Journal of Managerial Finance 13: 267-86. [CrossRef]

Villalonga, Belen, and Raphael Amit. 2006. How do family ownership, control and management affect firm value? Journal of Financial Economics 80: 385-417. [CrossRef]

Wach, Krzysztof. 2014. The Role of Knowledge in the Internationalisation Process: An Empirical Investigation among Polish Businesses. In International Competitiveness in Visegrad Countries: Macro and Micro Perspectives. Edited by Doris Kiendl-Wendner and Krzysztof Wach. Graz: Fachhochschule Joanneum, Chapter 7. pp. 143-58.

Wach, Krzysztof. 2017. Exploring the role of ownership in international entrepreneurship: How does ownership affect internationalisation of Polish firms? Entrepreneurial Business and Economics Review 5: 205-24. [CrossRef]

Welch, Lawrence, and Reijo Luostarinen. 1993. Inward-outward connections in internationalization. Journal of International Marketing 1: 44-56. [CrossRef]

Wernerfelt, Birger. 1984. A resource-based view of the firm. Strategic Management Journal 5: 171-80. [CrossRef]

Yudaeva, Ksenia, Konstantin Kozlov, Natalia Melentieva, and Natalia Ponomareva. 2003. Does foreign ownership matter. Economics of Transition 11: 383-409. [CrossRef]

Zaheer, Srilata. 1995. Overcoming the liability of foreignness. Academy of Management Journal 38: 341-63.

Zaheer, Akbar, and Exequiel Hernandez. 2011. The geographic scope of the MNC and its alliance portfolio: Resolving the paradox of distance. Global Strategy Journal 1: 109-26. [CrossRef]

Zahra, Shaker. 2003. International expansion of US manufacturing family businesses: The effect of ownership and involvement. Journal of Business Venturing 18: 495-512. [CrossRef]

Zhang, Hai-Yan, and Danny Van Den Bulcke. 1996. China: Rapid changes in the investment development path. In Foreign Direct Investment and Governments: Catalysts for Economic Restructuring. London: Routledge, pp. 380-422. 